\title{
A COMPARISON OF TWO RECENT JÖKULHLAUPS FROM AN ICE-DAMMED LAKE, SØNDRE STR ØMFJORD, WEST GREENLAND
}

\author{
By ANDREW J. RUSSELL
}

(Department of Geography, University of Aberdeen, Old Aberdeen AB9 2UF, Scotland)

ABstract. The hydrographs of two jökulhlaups resulting from the sudden drainage of an ice-dammed lake in West Greenland in 1984 and 1987 are compared. The first flood had a similar peak discharge to the second but drained only two-thirds of the total volume of the 1987 event which amounted to $32-36 \times 10^{6} \mathrm{~m}^{3}$ in $36 \mathrm{~h}$. Calculations based on the lake refill time suggest that it drains every 2-3 years, but that peak flows may be variable from flood to flood. The timing of the jökulhlaups in relation to the melt season may reflect variations of water pressure within the subglacial drainage networks, and changes in the configuration of these networks and the positions of crevasses on an annual basis.

\section{INTRODUCTION}

Many ice-dammed lakes in Greenland drain suddenly and at fairly regular intervals (e.g. Helk, 1966; Higgins, 1970; Dawson, 1983; Clement, 1984a, b) but little research has yet been undertaken to investigate the causes, effects, and variability of such events.

The aim of this paper is to compare the hydrographs of two jökulhlaups from the drainage of an ice-dammed lake in West Greenland and to explain the differences in terms of the nature and degree of variation between flood hydrographs produced from the same lake, and the variation in antecedent conditions for such drainings.

The source of floods discussed here is an ice-dammed lake about $30 \mathrm{~km}$ north-east of the Søndre Strømfjord airport (Figs 1 and 2). The lake occupies an ice-marginal embayment within an upland region of glacially scoured gneiss (Figs 3 and 4). The relief amplitude of this terrain is of the order of $200-300 \mathrm{~m}$ with only a few summits exceeding $600 \mathrm{~m}$ a.s.l. The lake is contained by an ice dam about $1.2 \mathrm{~km}$ in length forming a calving ice cliff $25-30 \mathrm{~m}$ high (Figs 3 and 4 ). The floods drain subglacially, emerging $1.25 \mathrm{~km}$ down-stream into an ice-marginal river-channel system, which follows a series of bedrock lake basins for $1.2 \mathrm{~km}$ before opening out into a wider valley sandur,

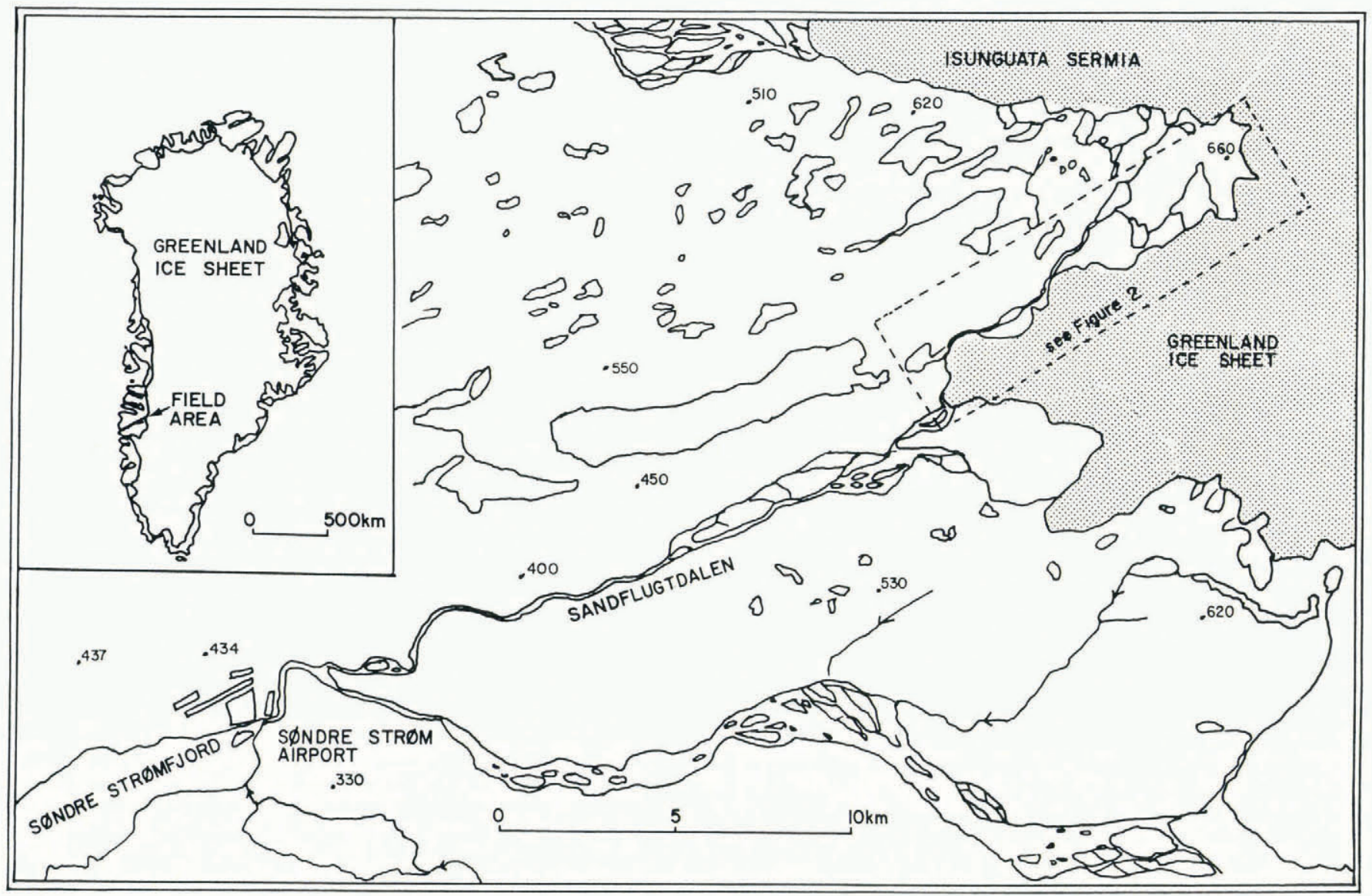

Fig. 1. Location of the field area in relation to Sondre Stromfjord, West Greenland. 


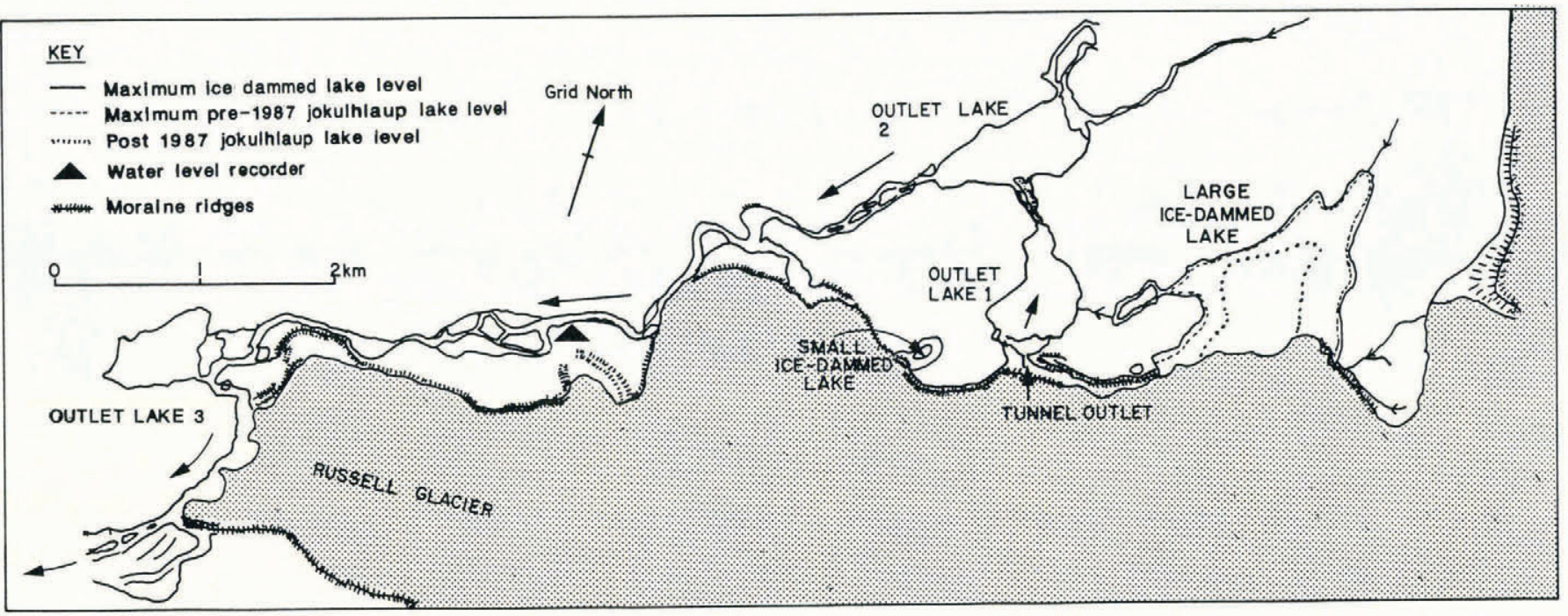

Fig. 2. Map of the field area showing the location of the large ice-dammed lake and the flood route.

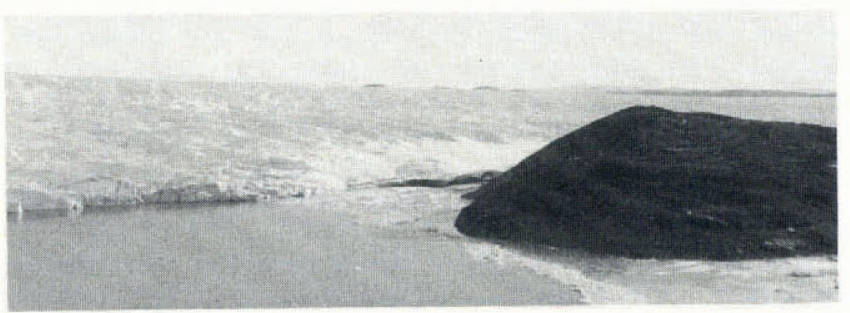

Fig. 3. Ice-dammed lake in October 1986 approximately $10 \mathrm{~m}$ below the maximum (spillway controlled) lake shoreline. View in a southerly direction over Russell Glacier.

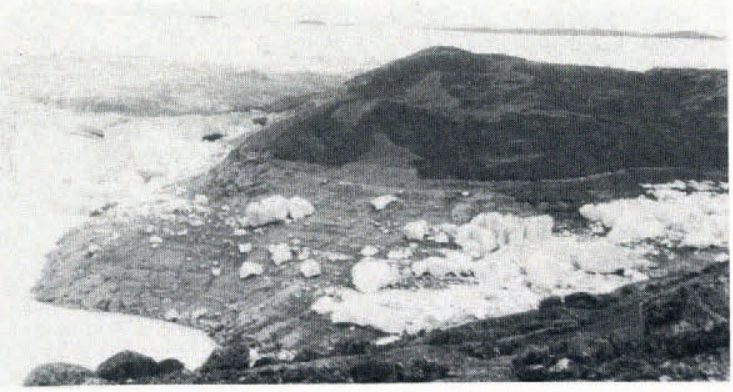

Fig. 4. Ice-dammed lake 21 July 1987 showing the roofs of the jökulhlaup drainage tunnels.

Sandflugtdalen, which extends a further $10 \mathrm{~km}$ south-west to Søndre Strømfjord (Figs 1 and 2). A jökulhlaup was monitored in July 1987, while previous jökulhlaups from the same lake had been noted in 1974 (Gordon, 1986) and in 1982 (personal communication from $\mathrm{H}$. Scholz) and observed in 1984 by Sugden and others (1985).

The duration, total volume drained, and peak discharge of jökulhlaups from an ice-dammed lake may vary in response to changes in rates of lake filling, variations in lake-basin volume as controlled by ice-margin fluctuations, changes in the drainage route, and variations in both ice and lake temperatures (Clarke, 1982). Variation in the timing of jökulhlaups may be controlled by seasonally influenced variations of hydrological conditions within the glacier (Röthlisberger, 1972). The nature and degree of variation between flood-discharge hydrographs from the same lake can be ascertained by comparing peak flood discharges, total volumes of water drained, and the duration of the jökulhlaups.

The 1987 jökulhlaup occurred during 17-19 July, lasting for $36 \mathrm{~h}$ (Fig. 5a and b). The 1984 jökulhlaup took place later in the year over a period $24 \mathrm{~h}$ on 20 August (Fig. 7).

\section{THE 1987 JÖKULHLAUP}

The jökulhlaup had a measured peak discharge of $1080 \mathrm{~m}^{3} \mathrm{~s}^{-1}$ in comparison with normal diurnal flows of $13-37 \mathrm{~m}^{3} \mathrm{~s}^{-1}$ during the melt season (Fig. 5a and b). The volume of water drained, as calculated from the measured hydrograph (Fig. 5b) was $31.4 \times 10^{6} \mathrm{~m}^{3}$ compared with $36 \times 10^{6} \mathrm{~m}^{3}$ estimated from the volume of water lost from the lake basin. Jökulhlaup discharge rose for $18 \mathrm{~h}$ before reaching a peak at $c .16 .00 \mathrm{~h}$ on 18 July (Fig. 5a and b). Large fluctuations of flow stage were present for the last $5 \mathrm{~h}$ of the rising limb before it decreased more quickly on the falling limb, taking $14 \mathrm{~h}$ to return to pre-flood levels (Fig. 5a and $b$ ).

The fluctuations in flow on the rising limb possibly reflect several phases of temporary reduction in the rate of tunnel enlargement. The latter is likely to have been governed by the transfer of heat from the lake water within the tunnel to the tunnel walls (Liestøl, 1956; Nye, 1976; Clarke, 1984). The periodic emergence of large ice blocks from the tunnel exit observed during this period suggests partial tunnel blockage was insufficient to completely shut off the flow (Fig. 4). Sturm and others (1987) invoked repeated tunnel blockage to explain three shut-offs of flow during the rising limb of a jökulhlaup from Strandline Lake, Alaska.

The volume of water that drained during the 1987 jökulhlaup was calculated both by monitoring flow stage during the flood and from the volume of water lost from the ice-dammed lake basin.

River-water levels were determined from a continuous stage record obtained at $10 \mathrm{~min}$ intervals before, during, and after the flood, using a pressure transducer and data-logger system (Fig. 5a). Depth and velocity profiles were determined prior to the jökulhlaup at the reach chosen for the recorder (Fig. 2). Surface velocities were measured by throwing floats into the centre of the channel and timing them through the gauged reach. These velocities, together with width and stage measurements, provide the basis for the flood stage-discharge rating curve, from which the discharge hydrograph (Fig. 5b) was derived. Channel-bed scour during the flood may mean that the calculated flood discharges are underestimated, for example, if the channel were deepened by $1 \mathrm{~m}$ during the flood, then the peak discharge would be $1300 \mathrm{~m}^{3} \mathrm{~s}^{-1}$, which is $210 \mathrm{~m}^{3} \mathrm{~s}^{-1}$ greater than the value assuming a stable channel.

The ice-dammed lake levels were surveyed relative to the maximum lake shoreline (Fig. 3) on three dates, two preceding and one following the 1987 jökulhlaup. Lake bathymetry was estimated from air photographs (scale $1: 17000$ ) taken in 1962 whilst the lake was partially empty. Lake-surface areas were calculated at estimated $10 \mathrm{~m}$ vertical intervals from the maximum shoreline. As the post-1987 jökulhlaup level was considerably lower than that on the 1962 air photographs, the largest error in the lake-volume calculations can be attributed to the 
RIVER STAGE
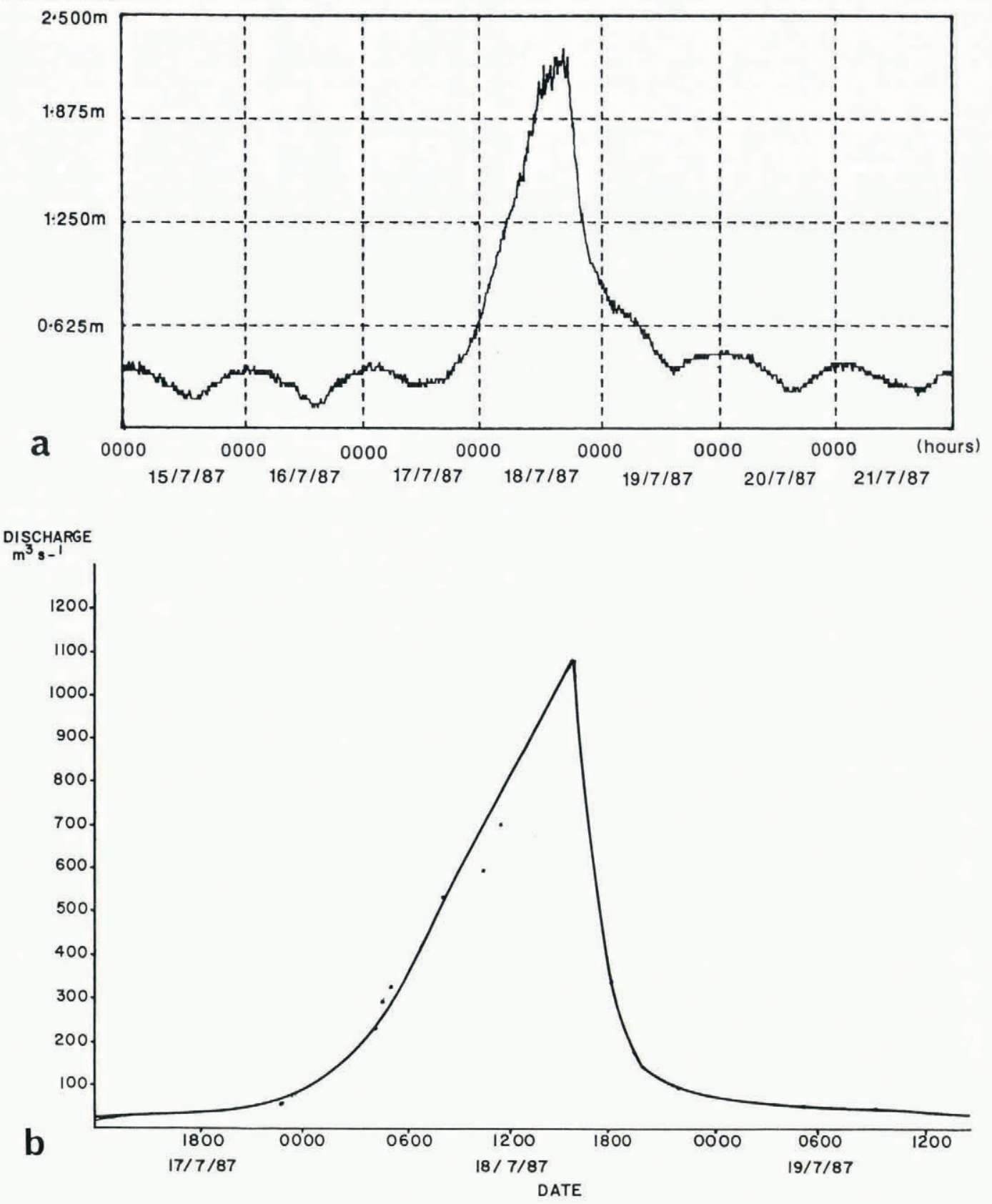

Fig. 5. a. River stage recorded at $10 \mathrm{~min}$ intervals for the 1987 flood. Vertical interval $0.025 \mathrm{~m}$ recorded by pressure transducer. b. 1987 jökulhlaup discharge measured at the gauged reach. Stage readings in Figure $5 a$ were used for each velocity measurement to calculate the discharge at each point.

interpolation of the contours, with an estimated maximum error of $\pm 2 \times 10^{6} \mathrm{~m}^{3}$. The amount of lake-level rise was observed between 17 June and 7 July 1987, giving a filling rate of $8.4 \times 10^{6} \mathrm{~m}^{3} / \mathrm{d}$ (Fig. 6). Assuming that this rate remained constant between 7 and 17 July, the lake would have risen to within $2.9 \mathrm{~m}$ of the maximum possible lake level (spillway controlled) immediately prior to the 1987 jökulhlaup (Fig. 6). This figure agrees closely with the maximum lake level indicated by a silt cover on vegetation observed within the basin after the lake had drained.

\section{THE 1984 JÖKULHLAUP}

To compare the two flood events, the hydrograph estimated by Sugden and others (1985) was re-examined (Fig. 7). Table I compares the 1984 and 1987 data. Due to the large difference $\left(26.66 \times 10^{6} \mathrm{~m}^{3}\right)$ between estimates of water volume derived from lake-basin size and that derived from the area under the plotted 1984 flood hydrograph (Sugden and others, 1985), it was necessary to re-plot the flood hydrograph (Fig. 7). The revised plot assumes that the volume of water lost from the lake basin equals the total flood discharge observed down-stream at the gauging station. The resulting hydrograph (Fig. 7) implies smaller volumes of water $\left(22 \times 10^{6} \mathrm{~m}^{3}\right.$ instead of $\left.49 \times 10^{6} \mathrm{~m}^{3}\right)$, although the duration and shape of the original hydrograph have been retained. This shows that the 1984 flood rose steadily on the rising limb for $12 \mathrm{~h}$ before dropping to pre-flood levels in $12 \mathrm{~h}$.

\section{COMPARISON OF THE 1984 AND 1987 JÖKULHLAUPS}

Comparison of the two hydrographs shows that the duration of the August 1984 flood was only two-thirds that of the July 1987 flood, and involved a much smaller volume of water.

Differences in peak flood discharge between the two flood events were also determined from the height of lakelevel rise in a series of three lakes through which the floods passed (Fig. 2). In outlet lake 1, the 1984 flood 
maximum level was $0.3 \mathrm{~m}$ lower than in 1987 (Table I), again suggesting that the last event had a higher peak discharge. Estimates of the volumes of water drained from the ice-dammed lake basin during the 1984 and 1987 jökulhlaups (Fig. 6) show that the amount lost in 1984 was not as large as that lost in 1987. The ice-dammed lake level prior to the 1984 jökulhlaup was $4.1 \mathrm{~m}$ lower than that prior to the 1987 drainage (Table I and Fig. 6). The 1987 jökulhlaup lowered the ice-dammed lake to a level $4.4 \mathrm{~m}$

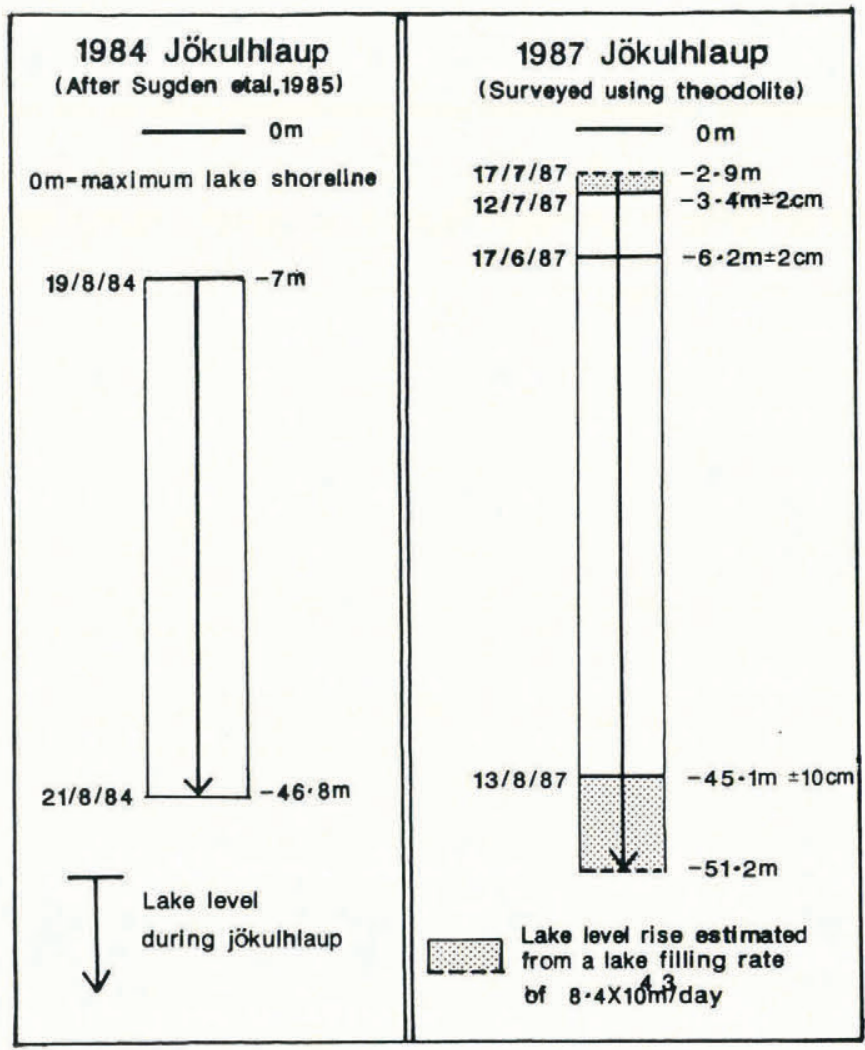

Fig. 6. Lake-level fluctuations during the 1984 jökulhlaup (after Sugden and others, 1985) and between June and September 1987. higher than following the 1984 event (Table I and Fig. 6). Comparison of peak flood discharge and total lake volume shows that these two events conform with discharge-volume relationships for six ice-dammed lakes described by Clague and Mathews (1973) (Fig. 8). This relationship is defined by $Q_{\max }=75 \mathrm{~V}$ max (where $Q=$ discharge in $\mathrm{m}^{3} \mathrm{~s}^{-1}$ and $V=$ volume of water lost from the lake during the jökulhlaup in $\mathrm{m}^{3}$ ). In addition to overall hydrograph differences, short-term irregularities are also apparent in the 1987 flood hydrograph which were not observed in the 1984 flood record. For example, the $5 \mathrm{~h}$ period of fluctuating water levels $(11.00-16.00 \mathrm{~h}, 18$ July 1987) on the rising limb of the flood was distinctive (Fig. 5a).

\section{DISCUSSION AND CONCLUSIONS}

\section{Year-to-year variations}

Comparison of the two flood events suggests that conditions vary from year to year. The factors influencing seasonal variations in lake drainage may reflect complex interactions between ice-marginal fluctuations, rates of filling, and water pressures within subglacial and englacial passages. The development of conditions suitable for lake drainage along this ice margin in July 1987 are demonstrated by the subglacial drainage of a smaller ice-dammed lake, lying $2 \mathrm{~km}$ south-west of the main icedammed lake (see Fig. 2), only 1 week earlier.

Röthlisberger (1972) suggested that melt-water streams occupy lateral positions within the glacier along the hydraulic grade line, which is defined as a line joining elevations to which water would rise in pipes freely vented and under atmospheric pressure. It is the physical connection between these channels and the ice-dammed lake which may result in an exponential increase in discharge associated with rapid tunnel enlargement due to the transfer of heat from the lake water to the tunnel walls (Liestøl, 1956; Röthlisberger, 1972; Clarke, 1984). This, however, will only take place if water pressures within the subglacial system are low and the hydraulic grade line is beneath the level of the ice-dammed lake. During early summer, water pressures are high due to large inputs of water into a conduit system of limited capacity (Röthlisberger, 1972). However, later in the summer, discharge either remains steady or decreases, producing a reduction of water

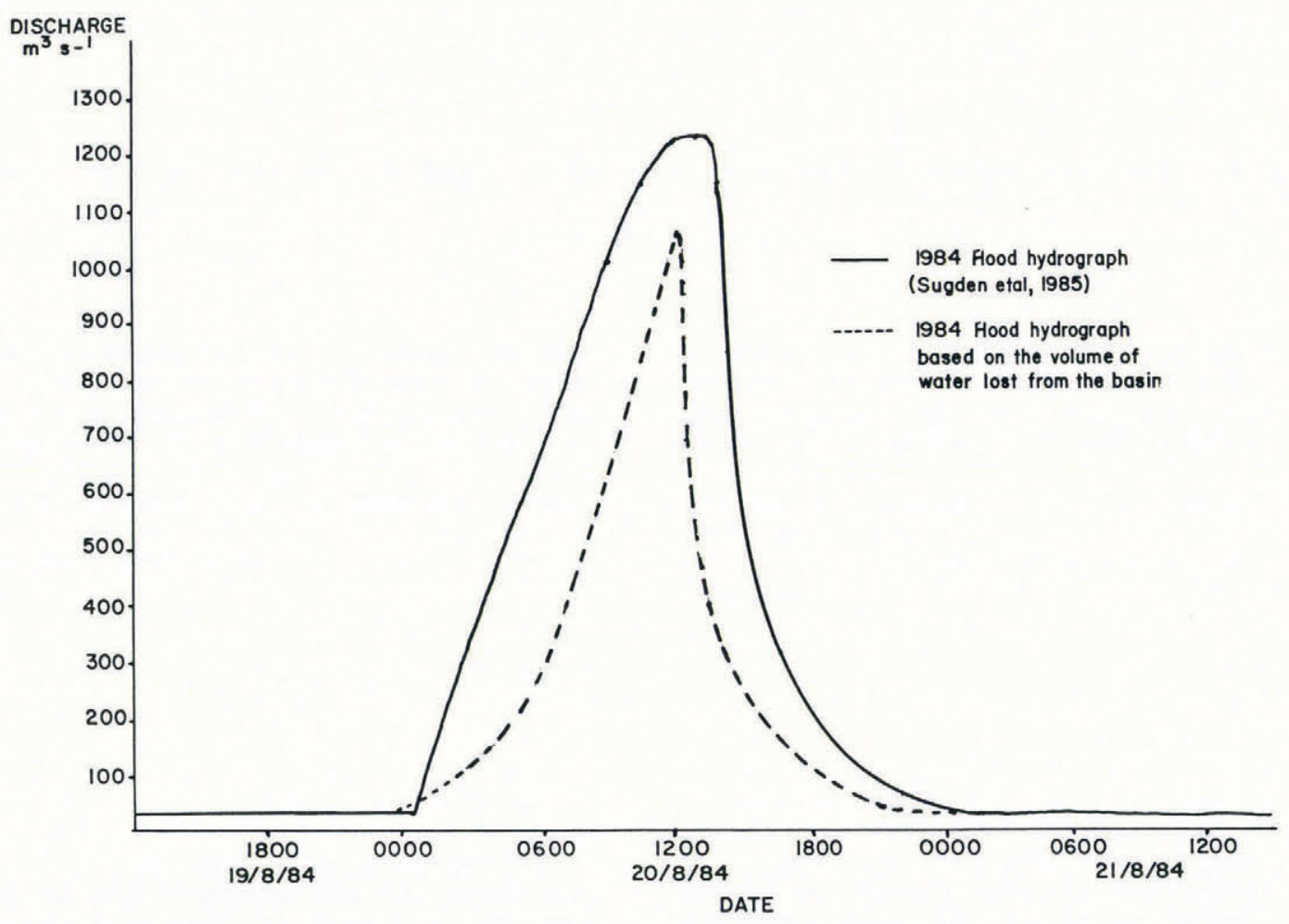

Fig. 7. The 1984 jökulhlaup (Sugden and others, 1985) showing recalculated hydrograph. 
1984

Lake level prior to draining

Level of drop

Volume lost:

(a) Calculated from lake volume lost

(b) Calculated from the hydrograph

Maximum level of outlet lake 1

Maximum level of outlet lake 2

Maximum level of outlet lake 3

Duration of jökulhlaup

Calculated peak discharge

Drainage route

Tunnel dimensions

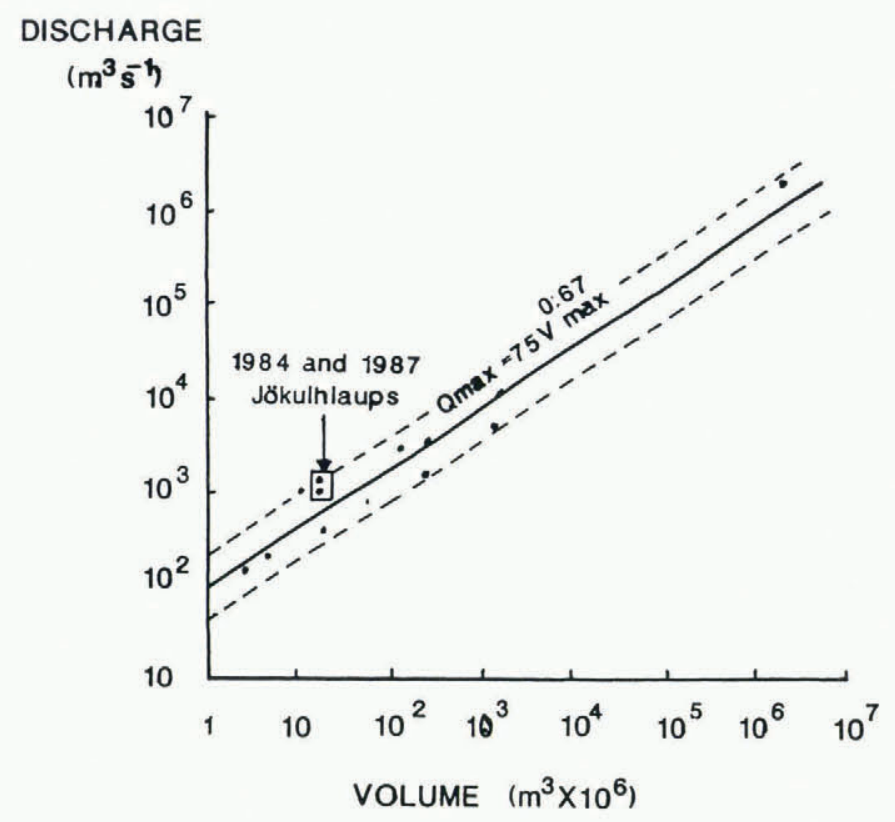

Fig. 8. Plot of the 1984 and 1987 jökulhlaups against the data used by Clague and Mathews (1973) to derive the empirical relation between peak flood discharge $\left(Q_{\max }\right)$ and total volume drained $\left(V_{\max }\right)$.

pressure. A lowering of both the water pressure and the elevation of the hydraulic grade line may result in the drainage of the ice-dammed lake. The timing, magnitude, and shape of flood hydrographs resulting from the drainage of this ice-dammed lake may be influenced by the above processes. The timing of this event will also depend upon climatic variables such as amounts of winter snowfall and rates of ice melting during the summer.

\section{Effects of tunnel closure}

So far it has been assumed that the lake is completely sealed off between flood events. This, however, may not always be the case where ice thicknesses are less than $50 \mathrm{~m}$ (Liestøl, 1956; Röthlisberger, 1972) and therefore insufficient to produce overburden pressures great enough to seal off the tunnels between drainage events. Ice thickness at the tunnel inlet is approximately $60 \mathrm{~m}$ (Fig. 4), falling to approximately $10-15 \mathrm{~m}$ at the tunnel outlet (Fig. 2). It is therefore possible that only the tunnel (or parts of the tunnel system) near the inlet becomes sealed off completely between drainage events where ice velocities and thicknesses are great enough. Variations in the frequency of lake drainage will determine the extent to which the tunnels have closed between drainage events. Comparison of the 1984 and 1987 flood hydrographs (Figs 5a and 7) shows that the 1984 flood had a relatively higher flood peak $\left(Q_{\max }\right.$ vs $\left.V_{\max }\right)$ than the 1987 flood; however, a flood in 1982 (personal communication from $\mathrm{H}$. Scholz) showed that 2 years were available for the closure of the jökulhlaup tunnels before the 1984 flood. This is in contrast to 3 years available for tunnel closure prior to the 1987 flood. As a
$7 \mathrm{~m}$ from max.

$39.8 \mathrm{~m}$

$22.3 \times 10^{6} \mathrm{~m}^{3}$
$49 \times 10^{6} \mathrm{~m}^{3}$
$?$
$+3.11 \mathrm{~m}$
$+2.58 \mathrm{~m}$
$22 \mathrm{~h}$
$1226 \mathrm{~m}^{3} \mathrm{~s}^{-1} \quad$ Same
One tunnel
$15 \mathrm{~m}$ in diameter
rapidly attained.

\section{REFERENCES}

1987

$2.9 \mathrm{~m}$ from max.

$48.3 \mathrm{~m}$

$36 \times 10^{6} \mathrm{~m}^{3}$

$31.4 \times 10^{6} \mathrm{~m}^{3}$

$+6.5 \mathrm{~m}$

$+3.44 \mathrm{~m}$

?

$36 \mathrm{~h}$

$1080 \mathrm{~m}^{3} \mathrm{~s}^{-1}$

Two tunnels

$10-15 \mathrm{~m}$ in diameter

consequence, the main jökulhlaup tunnel may have been incompletely sealed by ice deformation prior to the 1984 event, allowing relatively greater peak discharges to be more

If the thickness of the ice seal is reduced to less than $50 \mathrm{~m}$, then the lake may remain connected with the tunnel system from year to year. Such a situation would prevent the lake from filling to either the 1984 or 1987 pre-flood levels. After the 1987 event, soil and vegetation remnants were observed in situ $40 \mathrm{~m}$ below the maximum lake shoreline, suggesting a recent period during which the lake was unable to fill to present-day levels.

\section{Effects of jökulhlaup timing}

The timing of the jökulhlaups in relation to the melt season may be an important factor in determining the form of their hydrographs. Melting rates earlier in the summer may preclude the rapid propagation of subglacial or englacial passages, resulting in floods with relatively lower peak discharges of longer duration; this characterized the 1987 flood which occurred early in the melt season.

\section{Frequency of lake drainage}

Sugden and others (1985) suggested that lake drainage occurs annually. Gordon (1986) suggested a frequency of 2 years based upon the likely amount of water (unspecified) necessary to float the ice dam. This study estimates the likely frequency of drainage from calculations of filling rates, determined from 1987 lake-level measurements (see Fig. 6). These suggest that three melt seasons of $120 \mathrm{~d}$ are required for the lake to reach its 1987 level. Rates of filling are, however, likely to vary throughout the melt season and also from year to year.

The level at which the lake drains and to which it falls may also be related to seasonally dependent variables such as the water pressure within the subglacial and englacial drainage networks and the position of these networks in relation to the level of the ice-dammed lake. Seasonal crevasse propagation near the ice-dammed lake may result in the connection of the subglacial and englacial drainage networks with the lake. Lake-level evidence suggests that, under present climatic and glaciological conditions, the lake drains every 2 or 3 years.

\section{ACKNOWLEDGEMENTS}

I should like to thank Dr J.K. Maizels and Dr C.M. Clapperton for comments on earlier drafts of this manuscript and all the technical staff in the Department of Geography, University of Aberdeen, especially R. Gard; and E. Elvidge, C. de Jong, P.G. Knight, J. Sinclair, and P. Tollerup for assistance in the field. I am currently in receipt of a U.K. N.E.R.C. Research Studentship award.

Clague, J.J. and W.H. Mathews. 1973. The magnitude of jökulhlaups. J. Glaciol., 12(66), 501-504.

Clarke, G.K.C. 1982. Glacier outburst floods from "Hazard Lake", Yukon Territory, and the problem of flood magnitude prediction. J. Glaciol., 28(98), 3-21. 
Clarke, G.K.C. 1986. Professor Mathews, outburst floods, and other glaciological disasters. Can. J. Earth Sci., 23(6), 859-868.

Clement, P. 1984a. Observationer omkring Hullet - en isdæmmet sø i Sydgrønland. Dansk Geol. Foren. Arsskr. 1983, 65-71.

Clement, P. 1984b. The drainage of a marginal icedammed lake at Nordbogletscher, Johan Dahl Land, south Greenland. Arct. Alp. Res., 16(2), 209-216.

Dawson, A.G. 1983. Glacier-dammed lake investigations in the Hullet lake area, south Greenland. Medd. Gronl., Geosci. 11.

Gordon, J.E. 1986. Correspondence. Glacial lake drainage near Søndre Strømfjord, West Greenland. J. Glaciol., 32(111), 304

Helk, J.V. 1966. Glacier mapping in Greenland. Can. J. Earth Sci., 3(6), 771-774.
Higgins, A.K. 1970. On some ice-dammed lakes in the Frederikshåb district, south-west Greenland. Medd. Dansk Geol. Foren., 19(4), 378-397.

Liestøl, O. 1955. Glacier dammed lakes in Norway. Nor. Geogr. Tidsskr., 15(3-4), $122-149$.

Nye, J.F. 1976. Water flow in glaciers; jökulhlaups, tunnels and veins. J. Glaciol., 17(76), 181-204.

Röthlisberger, H. 1972. Water pressure in intra- and subglacial channels. J. Glaciol., 11(62), 177-203.

Sturm, M., J. Beget, and C. Benson. 1987. Observations of jökulhlaups from ice-dammed strandline lake, Alaska: implications for paleohydrology. In Mayer, L. and D. Nash, eds. Catastrophic flooding. London, Allen and Unwin, 79-94. (Binghamton Symposia in Geomorphology 18.) Sugden, D.E., C.M. Clapperton, and P.G. Knight. 1985. A jökulhlaup near Søndre Strømfjord, West Greenland, and some effects on the ice-sheet margin. J. Glaciol., 31(109), 366-368.

MS. received 21 December 1987 and in revised form 29 December 1988 